\title{
Character Education Through Dola Bololo in Early Childhood at Afe Taduma Ternate North Maluku, Indonesia
}

\author{
Sida Said ${ }^{\# *}$, Yufiarti^ and Moch. Syarief Sumantri^ \\ \#IAI Assiddiq Kieraha Ternate, North Maluku, Indonesia \\ ^Professor of Jakarta State University, Jakarta, Indonesia \\ Received 04 July 2018, Accepted 05 Sept 2018, Available online 07 Sept 2018, Vol.6 (Sept/Oct 2018 issue)
}

\begin{abstract}
The purpose of this article is to know the character education through Dola Bololo can give to early childhood, place, and time Dola Bololo is expressed to educate characters in early childhood in Afe Taduma Ternate. This study used ethnography qualitative methods to determine character education through Dola Bololo individually or in groups. The results show that character education can be provided through Dola Bololo for the formation of early childhood characteristics such as religious education, mutual assistance, togetherness, love of the nation, caring for nature. The Character education can be given at home, school and the environment. Dola Bololo is pronounced in poetry, syarhil, and sung at certain times.
\end{abstract}

Keyword: Character Education, Dola Bololo, Early Childhood

\section{Introduction}

Character education is a system to change the approach to addressing student effect, cognition, and behavior (Lopes et al., 2013). Good character is not formed automatically; it is developed over time through a sustained process of teaching, for example, learning and practice (Pala, 2011). Character education for early childhood is intended to instill good values as a basis for further personal development. Basically, the higher the education of a person, the higher the knowledge possessed, and this knowledge is used as a means to build the nation, besides that the character factors possessed by every citizen are also very important in building the nation. Therefore, the character of the nation should have been built together with its intellectual development.

Character education in Indonesia refers to several basic foundations, which have a clear and strong purpose, namely that character education does not occur deviations. The bases used are based on the results of an empirical study of the Center for Curriculum, including: religion, pancasila, culture, and national education.

The education held should not only be limited to developing one's knowledge or intellectual, but it should also improve one's character or character and even improve bad character to be good and more positive. However, efforts to build a person's character must be

*Corresponding author's ORCID ID: 0000-0002-6807-1820 DOI: https://doi.org/10.14741/ijmcr/v.6.5.1 started in early childhood, so that they will get children who have a character in the future. The main principle of good character is respect, truth, fairness, and responsibility (Skaggs, G., \& Bodenhorn, 2006). The benefits of character education are multifaceted going beyond the apparent outcomes of being a good person and responsible citizen (Almerico, 2014).

Character education defined right from a very long time, the educational systems of world spectrum had in many forms initiated some systems of educating pupils of different ages, and creed about the values of character (Agboola and Tsai, 2012). Building character since early childhood is considered very appropriate because they are still in the care of parents, not much influence from the outside environment other than the family environment, so parents more easily build children's character in accordance with their expectations and provide good role models for parents in shaping children's character is to provide various examples directly such as how to be honest, respect parents, respect each other, respect culture and so on. Early childhood, in general, will easily build a good character when looking directly at the closest people, namely parents, doing good deeds in everyday life. This happens because early childhood still prefers to imitate both through hearing and vision, and certainly has its own characteristics in building its character.

Similarly, the character of the Ternate tribe. To educate the character of early childhood is done in a variety of cultural ways, one of which is through Dola 
Bololo which is given since the child in parenting is done through poetry and songs. Since childhood, children have been accustomed to listening to Dola Bololo who is believed to be able to educate the character of a child. Ternate island community, which is predominantly Muslim, acts through habituation by using various media such as through cultural ceremonies, cultural dances, and also the poetry of Dola Bololo who has very educational character values. Integration of local wisdom is very essential and it could be executed by including the local wisdom values into the materials, allocated time for discussion on local wisdom, classroom activities and the process of teaching the linguistic skill (Albantani \& Madkur, 2018).

For the purpose of this literature review, first what character education can be educated through Dola Bololo, secondly where character education is carried out, and third When is character education carried out. The challenge and controversy of implementation of character education are also presented. Finally, the implication and further research are discussed.

\section{Review of Literature}

\section{Character Education}

Education is part of the structure of people's lives because only through the process of education can members of society be bound by various agreements in cultural structures called customs that are passed down from generation to generation. Character education is a growing discipline with the deliberate attempt to optimize students' ethical behavior (Agboola and Tsai, 2012). Character is the complex set of psychological characteristics that enable an individual to act as a moral agent (Berkowitz \&Bier, 2004)

Character education is a direct approach to moral education that involves basic moral teaching for students so as to prevent them from immoral behavior and do things that are harmful both for themselves and for others (santrock, 1999). Character education began to be heard again since the 1990s, was a Thomas Lickona who was considered as his bearer through his work "The Return of Character Education". This book brings change in the western world that character education is a necessity, and from here the beginning of the rise of character education.

The character is a complete unity between moral knowledge, moral feelings, and moral behavior, where the three things are interconnected, and good character consists of wanting and doing good things (Lickona, 1996). Character education is a national movement creating schools that foster ethical, responsible and caring young people by modeling and teaching good character through an emphasis on universal values that we all share (Pala, 2011).

Instructional activities useful for character and creativity education such as: Discussion, Collaborative
Activities, Experiential Activities, Role-Play, Reading Children's Literature, Storytelling, Inviting Community Experts (Lee, 2013).

The character is something that is unique only to individuals or to a group. That character is the foundation of cultural awareness, cultural intelligence and unifying culture character education in future community development that has competitiveness and independence, needs to synergize many things. The synergy is the first, religious values, cultural values, and individual potential; second, learning that educates knowledge of both skills (academic abilities) and soft skills (non-academic abilities). Third, efforts need to be made to develop, change, improve but by using good cooperation, hard work, quality thinking, honesty, efficiency, and democracy. And to create a mindset that has a competitive advantage as a nation, it is necessary to prepare a generation that has strategic capital namely good human resources, has well-ordered cultural capital, institutional capital and has good knowledge resources.

Character education in Indonesia refers to several basic foundations, which have a clear and strong purpose, namely that character education does not occur deviations. The foundations that are used based on the results of the empirical study of the Center for Curriculum include religion, Pancasila, culture, and national education goals. Character education efforts are influenced by the cultures in which they are implemented (Lee, 2013)

Eleven Principles of Effective Character Education (Lickona, Schaps and Lewis, 2002). These eleven principles were intended to define the essential elements of character education. Slightly abridged, these principles are 1. Character education promotes core ethical values. 2. "Character" is defined comprehensively to include thinking, feeling, and behavior. 3. Character education is intentional, proactive, and comprehensive. 4. The school is a caring community. 5. Students have opportunities for moral action. 6. The academic curriculum challenges al learners and helps them succeed. 7. The program develops students' intrinsic motivation to learn and to do the right thing. 8. All school staff share responsibility for modeling and promoting good character. 9. There is leadership from both staff and students. 10. Parents and community members are full partners in the characterbuilding effort. 11 . The evaluation assesses the character of the school, the school staff's functioning as character educators, and the extent to which students manifest good character.

Based on the above description it can be summarized that character education is a value, character, moral education, character, which aims to develop the ability of students to give good and bad decisions, maintain what is good, and realize goodness in daily life wholeheartedly.

\section{The Dola Bololo Culture}

Dola Bololo is composed of two words namely Dola which means movement, and Bololo which means feeling, thus 
the traditional sultanate of Ternate is called a movement that changes bad behavior towards good behavior to organize a better life in the future. Dola Bololo is one of Ternate's elements or oral literary forms that are equally important to play a role in people's lives both in interacting with Ternate people as well as speakers of other Ternate languages. This form of literature is often used by Ternate people in communicating to convey or express thoughts and feelings to others. The music media through the children's song lyrics can help to build the children character of the early age children. Children can explore their values of life from the meanings on the children's song lyrics which consist of values on education, knowledge, religious, social, and culture (Rosmiati, 2014).

Oral literature in Ternate is usually given from generation to generation to the present. Along with the development of Islam in this area, Ternate's oral literature was later written using Arabic script. In line with the development of the Ternate and Malay languages to become Lingua Franca in North Maluku. Then Ternate oral literature later became the property of the local community. This oral literature also gained influence from local languages, Malay, Arabic, Javanese, and French.

Ternate oral literature was used as a poem in the singing of regional art (sound art) to accompany traditional dances. But some are used to create a good character in the frame of indigenous culture.

So based on the presentation through sound art and poetry expression, Dola Bololo is combined with other types of oral literature, namely: (1) Dalil Tifa, (2) Dalil Moro, (3) Pantun, (4) Rorasa, (5) Bobaso se Rasai (6) Tamzil. All of them have different characteristics with one meaning which is to form a better human character, especially in early childhood.

\section{The Characteristics of Dola Bololo}

Dola Bololo in Ternate has a different characteristic, namely flash rhymes which are often placed in key positions in a conversation. While Togal and Lalayon are dances accompanied by a kick or song containing Dola Bololo. While the Dalil Moro and Dalil Tifa have different properties. The characteristics of each Dola Bololo are:

1. Dola Bololo about Mutual Value

2. Dalil Moro is a poem contained in Ternate oral literature. According to the Ternate community, the verses express statements, feelings, and opinions from ancestors which contain guidance and advice to someone in society. They are expected to be able to live a sense of family and can respect each other.

3. Dalil Tifa is talibun poem which contains instructions and advice and contains religious elements. The advice, instructions, and advice contained in Dalil Tifa mostly come from the teacher or announcer of Islam to his people to implement various provisions in accordance with the will of religion.
4. Tamzil in Ternate oral literature containing Islamic religious advice. Tamzil was delivered by a religious leader at the death ceremony with the aim that those present in the mourning atmosphere also felt what was felt by the grieving family at that time.

\section{Method}

\section{Location}

This research was carried out in the Afe Taduma Village, Ternate Island, North Maluku Province, Indonesia. Dola Bololo is still very strong as a community as a loca cultural tradition that is taught to early childhood, both in caring for children, while children play activities and serve as educational media in character planting. The uniqueness found in the community of Afe Taduma Village, Ternate Island Subdistrict which has a great desire to keep preserving and maintaining the ancestral culture of Dola Bololo as a means to create the character in early childhood.

This research on character education through Dola Bololo which is aimed at early childhood is qualitative research so it takes about one year.

\section{Subject}

Research subjects are parents and preschool children, traditional leaders, as well as experts who understand Dola Bololo.

\section{Data Collection}

Qualitative research with an ethnographic approach begins with the selection of a culture, a review of literature related to culture, and a meaningful identification of variables by members of the local culture. Data analysis and theory taking were carried out at the end of the study.

Primary data was obtained using methods: (1) interviews, (2) documentation with techniques to record images and collect archives, and (3) direct observation in the field related to character education in early childhood through Dola Bololo.

\section{Discussion}

Analysis of the results interviews and documents is carried out in stages, namely domain analysis, taxonomic analysis, component analysis, and Themes analysis. This type of character education through Dola Bololo in early childhood in Afe Taduma can generally be classified into two components, namely individual character education and social character education.

The Dola Bololo culture by the Ternate community is called Ternate Oral Literature. Dola Bololo is used to change the way of thinking and perspective of a person to give a better character to the community, especially to 
early childhood. So Dola Bololo is considered appropriate in character building since early childhood. Besides that, it was also noted that there were still many Afe Taduma people who could not use Indonesian well so that this Dola Bololo oral literature was used as a language to convey their intent and purpose.

Character education provided through Dola Bololo in early childhood is a tradition carried out by Afe Taduma Village community because it is believed to contain noble values that can educate the character of early childhood. Dola Bololo must always be heard to children from an early age until they grow up to become adults with positive values that are in line with the customs of the people according to the great expectations of the Afe Taduma community.

\section{Character education that can be educated through Dola Bololo}

Character education for early childhood through Dola Bololo because it has the content of advice, custom advice and noble values that can be used as guidelines in fostering family and community life. The concept of character education through Dola Bololo encompasses individual, family, and social character education. Consolidation of pedagogical practices that mediate the relationships between children and culture, it is possible to organize activities focusing on different dimensions of human development and personality (De Freitas Bissoli, 2014).

Character education can deepen the bond between parents and children, as well as significant influence the preschool Children's Character Cultivation, and also, the preschool parents support and scaffolding in children's storytelling, play, music, and arts serve as significant factors in preschool children's parent-child relationship (Mei-Ju, Chen-Hsin, \& Pin-Chen, 2014). All children can develop good moral behavior when teachers provide ongoing opportunities to experience proper actions and observe model behavior demonstrated by adults (Sanderse, 2013).

Parenting is the habit of parents to say Dola Bololo because they believe that there is a lot of advice and sublime messages about the meaning of life so that it can be used as a medium for character education in early childhood. Character education that is successfully given through Dola Bololo can be witnessed in every act or behavior of early childhood in their daily activities. The types of character education that can be educated through Dola Bololo in early childhood are individual character education such as: Value of togetherness, Mutual respect, protecting the environment, Religious, Humility, Establishment, Benefits of knowledge, Maintain friendship, Friendship, and Human needs.

Based on the results of the research, the following substantive theories can be formulated: "if good character behaviors have been demonstrated by early childhood characterized by religious behavior, helpful, maintaining togetherness, humble, caring for the environment, love for God, having fun, having an establishment, maintaining cleanliness, helping parents, respecting parents, the Dola Bololo has a very positive value and is very meaningful to be used as a medium of character education for early childhood both individual characters and social character ".

\section{Place of Character Education through Dola Bololo}

Character education through Dola Bololo and carried out in three places that are considered appropriate and correct, namely at home, at school and in the community. The cultivating of the character building through by entering of Pantun into textbooks at school. Examples an avid reader, compassion, love of peace, responsibility, good and humble, respectful and polite, friendship, honesty, discipline, hard work and perseverance (Kaswan, Dan, \& Nirbaya, 2011).

Dola Bololo for character education at home includes: Value of togetherness, Mutual respect, Maintaining the environment, and Humility. Parents invite children to say poetry Dola Bololo aims to invite children to have fun while providing character education. Character education is poured through messages in Dola Bololo that are read. Dola Bololo aside from the content, there were also messages that were written in the form of songs.

The messages conveyed include: 1) Parents provide character education through Dola Bololo directly to children when children are having fun; 2) through Dola Bololo parents can give advice to early childhood about good deeds; 3) Parents say Dola Bololo is usually when they are in the kitchen, in the dining room, in the yard of the house; 4) Dola Bololo poetry is an excellent opportunity to always be close to children while educating characters from an early age.

Dola Bololo for character education at school, includes: Value of togetherness, Mutual respect, Maintaining the environment, Humility, Religious, and Benefits of knowledge. The reason for choosing Dola Bololo is in school because the teacher reads it easily to children, and the child is easy to say and understand. This Dola Bololo sentence is not too long so it's easy to memorize by children. Images of character education are also used so that children better understand, for example Dola Bololo about maintaining togetherness, maintaining behavior, maintaining feelings, instilling good intentions, maintaining good steps, maintaining balance, maintaining attitude and deeds, all of this Dola Bololo as a very useful for character formation in early childhood. Teachers and parents need to keep in mind that they need not teach every good behavior; by treating children with respect, they naturally model the appropriate behaviors (Lee, 2013).

Messages from Bololo dola delivered at school include: (1) Dola Bololo can facilitate teachers in educating early childhood characters, (2) through Dola Bololo the teacher easily invites students to take daily actions that can reflect religious values, and (3) through Dola Bololo, the teacher can introduce the wisdom of 
local Ternate culture. Teachers believe positive character traits, such as caring, honesty, and manners, are important qualities to be developed during early childhood (Yang et al., 2011).

Dola Bololo for character education in the community: Value of togetherness, Establishment, Maintain friendship, Humility, Religious, and Establishment. Dola Bololo is not only presented or sung for early childhood at home, but this poem is spontaneously carried out when looking at early childhood togetherness in the school yard when they play, on a large field when early childhood gather, and when people gather in the room, they are also calling out to say Dola Bololo.

Based on the analysis of the results of this study, the substantive theory can be formulated as follows: character education taught through Dola Bololo in early childhood can be done in all places if all components and institutions participate and are involved and are responsible for character education together.

\section{Character Education Time through Dola Bololo}

Character education given to early childhood through Dola Bololo is carried out at every opportunity and every time. The aim is that character education given to children can run continuously and not be stopped in their daily atmosphere so that the character of early childhood is getting better. The most fundamental character education is accomplished with collaboration of family and through actions and practices at home (Berkowitz \& Bier, 2007).

As for the character education given to early childhood by parents is when children are together in the kitchen, they are: Value of togetherness, Mutual respect, Maintaining the environment, and Humility. Character education provided when early childhood is in the dining room: Value of togetherness, Religious, Mutual respect, and Humility. Dola Bololo which is given to early childhood while on the home: Value of togetherness, Mutual, respect, Protecting the environment, Humility, Religious, and Establishment.

Character education is the deliberate effort to help people understand, care about, and act upon core ethical values. When we think about the kind of character we want for our children, it is clear that we want them to be able to judge what is right, care deeply about what is right, and then do what they believe to be right, even in the face of pressure from without and temptation from within (Elkind and Sweet, 2004).

Character education has been demonstrated to be associated with academic motivation and aspirations, academic achievement, prosocial behavior, bonding to school, prosocial and democratic values, conflictresolution skills, moral-reasoning maturity, responsibility, respect, self-efficacy, self-control, self-esteem, social skills, and trust in and respect for teachers (Berkowitz \& Bier, 2004).

Based on the analysis of the results of the study, the substantive theory can be formulated as follows: if Dola Bololo can be made available in all places such as when an early child is in the kitchen, in the dining room or on the yard, then it means that character education through Dola Bololo in early childhood can be done in any condition because it has a positive impact, and can develop early childhood character education well.

\section{Conclusions}

This section discusses the conclusions and suggestions for character education through Dola Bololo which consists of factual findings and discussions which include: 1) Character education that can be educated through Dola Bololo 2) Place of character education through Dola Bololo, 3) Time for character education through Dola Bololo. Taken together, parents, teachers, and administrators as stakeholders, should join this camp to encourage students to manifest those good values in their lives (Agboola and Tsai, 2012).

The suggestion that can be taken from the results of research for parents is to keep preserving Dola Bololo so as to continuously preserve it to educate the character of early childhood. Besides that, the community as the second element is responsible for participating in providing character education to children of the age, so that they are able to answer all the problems that arise with good character characteristics and praise. The community should also continue to preserve and present Dola Bololo, the Dalil Tifa for Dalil Moro to early childhood as the nation's next generation, religion and culture.

After the child enters school age, the child is familiar with the other world that is the third world after his home and environment, therefore the teacher is responsible for participating in giving characteristic education to students through the local culture in their area.

Customary leaders who control Dola Bololo are expected to maintain and preserve and socialize with various groups of people so that the Dola Bololo is increasingly recognized by the people of Ternate Island.

In addition, the government must participate and be able to develop and preserve the Dola Bololo, so that it can be known throughout the community and make it as a medium of character education for early childhood, given through several activities that can lead to early childhood love such as holding a syarhil competition Dola Bololo, race to say poetry Dola Bololo, and can create books related to Dola Bololo.

Recognizing the importance of Dola Bololo which is used as a medium of character education for early childhood, and considering the limitations of this research, it is hoped that there are researchers who are interested in conducting further research on character education through the Dola Bololo. In addition, what is more, important is that we can do more in-depth research about the Dola Bololo so that the Dola Bololo can be the basis of a complete theory to study local cultural wisdom for character education in North Maluku Province. 


\section{References}

[1]. Albantani, A. M., \& Madkur, A. (2018). Think globally, act locally: the strategy of incorporating local wisdom in foreign language teaching in Indonesia. International Journal of Applied Linguistics \& English Literature, 7(2), 18. https://doi.org/10.757/ aiac.ijalel.v.7n.2p.1

[2]. Alex Agboola and Kaun Chen Tsai. (2012). Bring Character Education into Classroom. European Journal Of Educational Research, 1(2), 163-170.

[3]. Almerico, G. M. (2014). Building character through literacy with children's literature. Research in Higher Education Journal, 26, 1-13.

[4]. Berkowitz, M. W., \& Bier, M. C. (2004). Research-Based Character Education. The ANNALS of the American Academy of Political and Social Science, 591(1), 72-85. https://doi.org/10.1177/0002716203260082

[5]. Berkowitz, M. W., \& Bier, M. (2005). Character education: Parents as partners. Educational Leadership, 63(1), 64-69.

[6]. David Elkind \& Freddy Sweet Ph.D. 2004. How to do character education. (http://www.goodcharacter.com/Article_4.html)

[7]. De Freitas Bissoli, M. (2014). Development of children's personality: The role of early childhood education. Psicologia Em Estudo, 19(4), 587-597. https://doi.org/10.1590/1413-73722163602

[8]. Kaswan, K., Dan, D., \& Nirbaya, R. (2011). Penanaman Pendidikan Karakter Melalui Pantun Dalam Buku Bahasa Indonesia 4 : Untuk SD Dan MI Kelas IV Pendahuluan NilaiNilai Pendidikan Karakter, 60-70.

[9]. Lee, G.-L. (2013). Re-emphasizing Character Education in Early Childhood Programs: Korean Children's Experiences. Childhood Education, 89(5), 315-322. https://doi.org/ 10.1080/ 00094056.2013. 830907.

[10]. Lickona, T. (1996). Eleven principles of effective character education. Journal of Moral Education, 25(1), 93-100. https://doi.org/ 10.1080/ 0305724960250110.
[11]. Lickona, T., E. S. and C. L. (2002). Eleven Principles. Eleven Principles of Effective Character Education.

[12]. Lopes, J., Oliveira, C., Reed, L., \& Gable, R. A. (2013). Character Education in Portugal. Childhood Education, 89(5), 286-289. https://doi.org/ 10.1080/ 00094056.2013 .83088

[13]. Mei-Ju, C., Chen-Hsin, Y., \& Pin-Chen, H. (2014). The Beauty of Character Education on Preschool Children's Parent-child Relationship. Procedia - Social and Behavioral Sciences, 143, 527-533. https://doi.org/10.1016/ j.sbspro.2014.07.431

[14]. Pala, A. (2011). The Need for Character Education International Journal of Social Sciences and Humanity Studies, 3(2), 23-32. Retrieved from http://www.sobiad.org/ejournals/journal_ijss/arhieves/20 11 2/aynur_pala.pdf.

[15]. Rosmiati, A. (2014). Teknik Stimulasi Dalam Pendidikan Karakter Anak Usia Dini melalui Lirik Lagu Dolanan. Resital: Jurnal Seni Pertunjukan, 15(1), 71-82. Retrieved from http://journal.isi.ac.id /index.php/resital/article/view/801/15.

[16]. Said Mursi, Syaikh Muhammad, Seni Mendidik Anak. Jakarta: Pustaka Al-Kautsar, 2001

[17]. Sanderse, W. (2013). The meaning of role modelling in moral and character education. Journal of Moral Education, 42(1), 28-42. https://doi.org/10.1080/ 03057240.2012 .690727$.

[18]. Skaggs, G., \& Bodenhorn, N. (2006). Relationships between implementing character education, student behavior, and student achievement., 18(1), 82-114.

[19]. Yang, S. S., Lee, K. E., \& Oh, J. K. (2011). A study on vitalizing character education through creative handson activities. (Research Report 2011-7-2). Seoul, Korea: Korean Educational Development Institute. 